\title{
ANALISIS MINAT BELAJAR SISWA PADA MATA PELAJARAN FISIKA DI SMA NEGERI 2 KOTA JAMBI
}

\author{
Ika Wahyuni ${ }^{1}$, Maison ${ }^{2}$, Haerul Pathoni ${ }^{3}$ \\ 1,2,3 Prodi Pendidikan Fisika Universitas Jambi, Indonesia \\ Corresponding author email: ika.wahyuni1993@gmail.com
}

Submit: 18 Maret 2021 $\quad$ Accepted: 22 April 2021 $\quad$ Publish: 30 April 2021

\begin{abstract}
Abstrak:
Pemilihan kelompok peminatan mata pelajaran pada tingkat SMA yang dilakukan oleh siswa pada Kurikulum Tahun 2013 berkaitan dengan kemampuan dasar umum (kecerdasan), bakat, minat dan juga kecenderungan pilihan dalam mencapai hasil belajar yang maksimal. Namun hal ini tidak sepenuhnya menjamin siswa yang memilih kelompok peminatan Matematika dan Ilmu Alam (MIA) tidak mengalami kesulitan dalam mempelajari pelajaran bidang IPA. Penelitian ini bertujuan untuk mengetahui minat belajar siswa pada mata pelajaran Fisika di SMA Negeri 2 Kota Jambi. Penelitian ini menggunakan metode deskriptif-kualitatif. Subjek penelitian adalah siswa kelas XI MIA 3 yang berjumlah 8 orang. Teknik pengumpulan data dilakukan dengan cara observasi, wawancara dan dokumentasi. Analisis data dilakukan secara deskriptif dengan uji keabsahan data melalui triangulasi. Hasil penelitian menunjukkan bahwa minat belajar siswa pada pelajaran Fisika dilihat dari sikap, kesadaran diri dan kesiapan siswa saat belajar. Siswa cenderung menyukai materi fisika yanf banyak melibatkan kemampuan berhitung. Metode pembelajaran yang digunakan guru mempengaruhi tingkat ketertarikan siswa untuk belajar. Pemberian tugas yang terlalu banyak bagi siswa menyebabkan penurunan minat belajar siswa.
\end{abstract}

Kata kunci: Minat belajar siswa, fisika

\begin{abstract}
The selection of groups of specialization subjects at the senior high school level carried out by students in the Nasional Curriculum is related to general basic abilities (intelligence), talents, interests and also the tendency of choice in achieving maximum learning outcomes. However, this does not fully guarantee that students who choose the Mathematics and Natural Sciences group will not experience difficulties in learning science subjects. This study aims to determine students' interest in learning in physics at senior high school 2 in Jambi City. This study used descriptive qualitative method. The research subjects were students of $11^{\text {th }}$ grade of Mathematics and Natural Sciences group, amounting to 8 people. The data collection technique was done by means of observation, interview and documentation. Data analysis was carried out descriptively by testing the validity of the data through triangulation. The results showed that students' interest in learning in physics was seen from the attitudes, self-awareness and readiness of students when learning. Students tend to like physics material which involves a lot of numeracy skills. The learning method used by the teacher affects the level of student interest in learning. Giving too many assignments for students causes a decrease in student interest in learning.
\end{abstract}

Keywords: Student interest in learning, physics

Copyright @ 2021 Physics and Science Education Journal (PSEJ) 


\section{Physics and Science Education Journal (PSEJ) \\ Volume 1 Nomor 1, April 2021}

\section{Pendahuluan}

Setiap siswa berhak memilih kelompok peminatan yang sesuai dengan kemampuan dasar umum (kecerdasan), bakat, minat dan juga kecenderungan pilihan dalam mencapai hasil belajar yang maksimal. Dalam proses penentuan kelompok peminatan jika mengacu pada pedoman peminatan SMA dan SMK yang dikeluarkan oleh Kementerian Pendidikan dan Kebudayaan tahun 2013, dapat dilakukan dengan jalur tes tertulis yang berupa tes psikologi, angket/kuisioner maupun tes materi mata pelajaran dan dengan jalur non tes (penentuan jurusan berdasarkan koordinasi antar guru mata pelajaran, wali kelas, orang tua siswa dan guru bimbingan konseling) serta dengan melihat hasil Ujian Nasional siswa. Peminatan peserta didik merupakan suatu proses pengambilan pilihan dan keputusan oleh siswa yang didasarkan pada pemahaman potensi diri dan peluang yang ada. Sistem kelompok peminatan seperti ini diharapkan mampu memberikan gambaran pada siswa tentang bidang apa sebenarnya yang mereka minati dan sesuai dengan kemampuan belajar siswa.

Namun sepertinya tujuan dari pemilihan kelompok peminatan belum dapat diwujudkan secara maksimal. Berdasarkan hasil observasi dan wawancara yang telah dilakukan, sebagian siswa SMA/MA yang memilih kelompok peminatan Matematika dan Ilmu Alam (MIA) menuturkan bahwa mereka juga mengalami kesulitan dalam mempelajari mata pelajaran pada bidang IPA terutama pelajaran Fisika. Ratarata siswa mengalami kesulitan dalam menganalisa permalasahan yang terdapat dalam soal-soal Fisika, dan didukung pula dengan kemampuan berhitung siswa dalam memproses dan menyelesaikan soal-soal Fisika juga masih kurang baik. Selain itu ditemukan pada sejumlah siswa status sebagai siswa peminatan Matematika dan Ilmu Alam (MIA) memang sangat dibanggakan oleh siswa.Mereka merasa hebat dan bangga jika bisa belajar dikelompok peminatan tersebut dan status mereka sebagai siswa peminatan Matematika dan Ilmu Alam (MIA). Namun hal tersebut ternyata tidak berbanding lurus pula hasil belajar yang mereka tunjukan. Kebanyakan dari siswa yang masuk dalam kategori tersebut tergolong siswa yang lemah dalam pelajaran IPA terutama Matematika dan Fisika.

Pada Kurikulum tahun 2013 yang digunakan pada sebagian besar sekolah saat ini dirancang untuk memberikan kesempatan kepada peserta didik belajar berdasarkan minat mereka, hal ini diperlihatkan dari proses pemilihan kelompok peminatan oleh siswa. sehingga dapat dikatakan bahwa pemilihan kelompok peminatan mata pelajaran yang dilakukan oleh siswa memiliki kaitan erat dengan minat belajar siswa. Berdasarkan permasalahan yang muncul tersebut sangat menarik perhatian untuk dilakukan suatu penelitian untuk meneliti lebih lanjut mengenai bagaimana minat belajar siswa pada mata pelajaran Fisika di SMA. Dimana meliputi faktor dan alasan apa saja yang mempengaruhi minat belajar siswa pada mata pelaran Fisika serta bagaimana pula sikap dan ciri-ciri khusus siswa yang memiliki minat belajar terhadap pelajaran Fisika di SMA. Serta untuk memahami lebih jauh permasalahan yang dihadapi oleh siswa yang memperngaruhi minat belajar siswa pada mata pelajaran Fisika.

Berdasarkan latar belakang, pertanyaan yang diajukan dalam penelitian ini adalah bagaimana minat belajar siswa pada mata pelajaran Fisika di SMA Negeri 2 Kota Jambi? Tujuan penelitian ini untuk mengetahui bagaimana sebenarnya minat belajar siswa pada mata pelajaran Fisika di SMA Negeri 2 Kota Jambi.

\section{Metode Penelitian}

Penelitian ini merupakan penelitian deskriptif-kualitatif. Menurut Sugiyono (2013) metode penelitian kualitatif sering disebut metode penelitian naturalistik, karena penelitiannya dilakukan pada kondisi yang alamiah dan objek yang alamiah pula tanpa adanya manipulasi situasi. Bogdan dan Biklen (Dwilestari,2012) juga menyebutkan beberapa karakteristik penelitian kualitatif yaitu: (1) Naturalistik, (2) Data deskriptif, (3) Fokus pada proses, (4) Induktif dan (5) Bermakna.

Tempat Penelitian dan Waktu

Penelitian dilaksanakan di SMA Negeri 2 Kota Jambi dalam kurun waktu tiga bulan, dimulai pada tanggal 12 Agustus 2015 hingga 5 November 2015. 
Instrumen Penelitian

Menurut Sugiyono (2013) dalam penelitian kualitatif, yang menjadi intrumen atau alat penelitian adalah peneliti itu sendiri. Maka pada penelitian deskriptif-kualitatif ini yang menjadi instrumen utama adalah peneliti sendiri. Kemudian setelah masalah yang dipelajari jelas maka peneliti menggunakan intrumen berupa interview protocol dan observasional protocol.

\section{Sumber Data}

Dalam penelitian ini digunakan teknik pemilihan sumber data berupa purposive sampling dengan jenis snowball sampling. Dengan sumber data penelitian yaitu guru mata pelajaran Fisika, dan siswa jurusan IPA kelas XI.

Teknik Pengumpulan Data

Dalam penelitian ini tahap pengumpulan data dilakukan pada natural setting (kondisi yang alamiah), sumber data primer, dan teknik pengumpulan data lebih banyak pada teknik: (1)observasi berperan serta (participan observation) golongan partisipan pasif, (2)wawancara mendalam (in-depth interview) dan (3) dokumentasi.

\section{Teknik Analisis Data}

Analisis data dalam penelitian kualitatif dilakukan sejak sebelum memasuki lapangan, selama di lapangan, dan setelah selesai di lapangan. analisis yang dilakukan adalah analisis yang disesuaikan dengan teknik pengumpulan data, dimana pada penelitian ini dilakukan analisis hasil wawancara, analisis hasil observasi dan analisis dokumentasi. Kemudian proses analisis data terhadap hasil wawancara, hasil observasi dan dokumentasi yang telah didapatkan akan diproses dengan beberapa tahapan yaitu sebagai berikut sesuai dengan Creswell (2012):

1. Tahap pertama

Pada tahap ini peneliti melakukan pengumpulan dan pengelompokkan data sesuai dengan tipe data (data wawancara, data observasi (fieldnotes) dan data dokumentasi).

2. Tahap kedua

Pada tahap kedua ini dilakukan proses transcribe data, yaitu mengubah semua tipe data yang telah disebutkan pada tahap pertama tadi kedalam bentuk teks sedetail mungkin.

3. Tahap ketiga

Tahap ketiga ini yaitu proses pengkodean data, pada tahap ini data-data yang telah ditranskrip dalam bentuk teks akan dibagi ataupun dikelompokkan menjadi bagian-bagian tertentu berdasarkan tema yang muncul dalam data.

4. Tahap keempat

Tahap keempat yaitu proses mencari dan menentukan tema dari data-data yang telah didapatkan yang akan dilaporkan pada laporan penelitian. Pada semua tahapan analisis harus dilakukan sedetail mungkin dan harus sesuai dengan data-data yang telah didapatkan.

Pengujian Keabsahan Data

Uji keabsahan data dalam penelitian, sering hanya ditekankan pada uji validitas dan reliabilitas. Menurut Sugiyono (2013) validitas merupakan derajat ketepatan antara data yang terjadi pada objek penelitian dengan daya yang dapat dilaporkan oleh peneliti. Dan validitas sendiri terbagi dua yaitu validitas internal dan validitas eksternal.Dalam penelitian kualitatif yang lebih utama adalah aspek nilai kebenaran yang berupa validitas internal, dimana untuk menguji valitidas internal dilakukan uji kredilitas data. Maka dalam penelitian deskriptif-kualitatif ini lebih mengutamakan pada uji kredibilitas data. Dimana uji kredibilitas data dilakukan dengan tahapan:

1. Perpanjangan pengamatan

2. Triangulasi data 
3. External audit

4. Membercheck

\section{Hasil Penelitian dan Pembahasan}

Gambaran Lokasi Penelitian

Lokasi penelitian dilaksanakan di SMA NEGERI 2 Kota Jambi yang beralamat di Jl. Pangeran Antasari RT 18 Kelurahan Talang Banjar Kecamatan Talang Banjar Kota Jambi. Jumlah siswa adalah sebanyak 1190 orang siswa terbagi dalam 2 kelompok paminatan yaitu Matematika dan Ilmu Alam (MIA) dan Ilmu-Ilmu Sosial (IIS). Sekolah ini dilengkapi dengan fasilitas sarana dan prasarana sekolah yang cukup lengkap guna mendukung proses pembelajaran di sekolah yang lebih maksimal.

\section{Pemilihan Kelas Subjek Penelitian}

Pada penelitian ini peneliti khusus mengamati minat belajar Fisika siswa pada kelas XI. Pihak sekolah memberikan kesempatan kepada peneliti untuk melaksanakan penelitian terhadap empat kelas yaitu kelas XI MIA 1, kelas XI MIA 2, kelas XI MIA 3 dan kelas XI MIA 4. Untuk menentukan lokasi subjek penelitian yang cocok maka langkah awal yang dilakukan peneliti adalah melakukan observasi kegiatan pembelajaran terhadap kegiatan pembelajaran Fisika yang meliputi aspek kegiatan pembelajaran, kondisi kelas, keadaan siswa saat kegiatan pembelajaran, maupun respon siswa terhadap peneliti sebagai orang asing yang melakukan pengamatan di ruang belajar mereka.

Setelah dilakukan observasi sebanyak dua kali untuk setiap kelas, dengan berbagai pertimbangan dari peneliti dan juga setelah dilakukan berbagai pendekatan secara personal terhadap beberapa siswa pada empat kelas tersebut maka peneliti memilih untuk menetapkan kelas XI MIA 3 sebagai lokasi penelitian yang lebih khusus. Dengan pertimbangan bahwa secara personal, siswa yang ada di kelas XI MIA 3 dapat lebih mudah diajak untuk berkomunikasi oleh peneliti dibandingkan siswa di tiga kelas lainnya, serta sikap terbuka mereka pada peneliti menjadi alasan peneliti untuk mudah mendapatkan informasi mengenai diri mereka.

Tahap pengumpulan data

Langkah awal yang dilakukan dalam penelitian saat memasuki lokasi penelitian adalah melakukan observasi, dengan objek observasi adalah kegiatan pembelajaran yang dilaksanakan di kelas XI MIA 3 SMA Negeri 2 Kota Jambi. Observasi terhadap kegiatan pembelajaran Fisika telah dilaksanakan sebanyak tujuh kali observasi. Pada observasi ini peneliti bertindak sebagai observer partisipan pasif, yaitu observer hanya melakukan pengamatan secara murni tanpa adanya keterlibatan secara langsung dengan objek pengamatan. Selain mengamati kegiatan pembelajaran secara umum, observer juga secara khusus mengamati sikap siswa pada saat kegiatan pembelajaran Fisika. Pada tahap observasi inilah merupakan kesempatan untuk menentukan siapa saja siswa yang cukup potensial untuk dapat dijadikan subjek penelitian.

Selain melakukan observasi, guna memenuhi pengambilan data yang valid, peneliti juga menggunakan teknik pengumpulan data berupa interview. Interview ini sendiri dilaksanakan dengan objek interiview adalah siswa-siswa yang peneliti anggap mampu memberikan informasi pribadi mengenai dirinya. Objek interview yang berjumlah delapan orang, peneliti pilih berdasarkan hasil pengamatan yang telah dilaksanakan sebelumnya. Interview terhadap siswa dilaksanakan diluar jam pelajaran sekolah dan telah dilaksanakan sebanyak tujuh kali interview terhadap beberapa siswa.

Minat Belajar Fisika Siswa

Setelah dilaksanakan penelitian dan juga pengolahan data secara kualitatif, ditemukan bahwa minat belajar siswa dapat dilihat kesiapan siswa dalam belajar di sekolah. Kesiapan belajar sendiri berkaitan dengan kesiapan jasmani maupun rohani siswa. Tentunya kesiapan belajar setiap individu siswa juga pasti berbeda-beda pula. Saat dilakukan wawancara dan juga observasi kegiatan pembelajaran Fisika terlihat ada siswa yang kesiapan belajarnya cukup baik, dan ada pula yang terlihat kurang tertarik untuk belajar. Kesiapan belajar pada beberapa siswa dipengaruhi oleh persepsi siswa terhadap pelajaran yang diterimanya saat proses pembelajaran di sekolah berlangsung.

Metode pembelajaran yang paling sering digunakan oleh guru adalah lebih banyak dengan cara ceramah dan juga mendiktekan materi yang diajarkan, guru jarang sekali menggunakan media papan tulis sebagai alat bantu dalam kegiatan pembelajaran, tentu saja hal tersebut bagi siswa dinilai kurang efektif untuk mendapatkan hasil belajar yang maksimal. Selain itu penggunaan media pembelajaran juga masih dirasa kurang maksimal, karena media pembelajaran yang digunakan juga kurang bervariasi. Sehingga 
menyebabkan antusias siswa untuk belajar juga dipengaruhi oleh hal tersebut. Secara tidak langsung pemilihan metode pembelajaran yang digunakan oleh guru pada saat mengajar juga akan mempengaruhi minat siswa dalam belajar, semakin baik metode dan juga teknik pembelajaran yang digunakan maka akan membentuk pengalaman belajar yang akan berpengaruh pada pembentukan minat belajar siswa. namun jika sebaliknya, pemilihan metode pembelajaran yang kurang tepat akan membuat penurunan terhadap minat belajar siswa itu sendiri.

Dalam menjalankan metode pembelajaran dengan maksimal, diperlukan pula teknik pembelajaran yang baik pula. Interaksi antara guru dan siswa pada saat proses pembelajaran berlangsung ternyata jug a mampu memberikan sumbangan bagi pembentukan minat belajar siswa. semakin baik interaksi guru dengan siswa maka siswa akan merasa semakin tertarik dan nyaman saat belajar, dan begitu pula sebaliknya.

Metode pembelajaran dengan cara pemberian latihan dan juga tugas rumah kepada siswa memang sangat dibutuhkan dalam meningkatkan keterampilan dan juga pemahaman siswa terhadap materi yang telah diajarkan oada saat proses pembelajaran. Hanya saja, jika kegiatan pemberian tugas ataupun latihan ini dirasa cukup banyak, maka hal ini tentu akan membuat siswa merasa sangat terbebani akan banyaknya tugas yang diberikan. Ketika siswa merasa terbebani akan banyaknya tugas, kemudian ditambah dengan timbal balik atas tugas yang sudah dikerjakan oleh siswa itu tidak sebanding, misalkan tugas tersebut tidak diberikan suatu nilai oleh guru, maka hal ini akan menimbulkan suatu rasa malas bagi siswa untuk mengerjakan tugas yang diberikan selanjutnya. Rasa malas itu jika dibiarkan maka akan menimbulkan rasa kurang tertarik untuk belajar. semakin siswa tidak tertarik untuk belajar maka minat belajar siswa juga akan semakin menurun. Jika hal in terus menerus terjadi, maka bisa saja berimbas pada hasil belajar yang akan didapatkan oleh siswa. oleh sebab itu perlu dipertimbangkan kembali metode pembelajaran dengan pemberian tugas ataupun latihan. Timbal balik atas tugas yang telah dilaksanakan oleh siswa harus seimbang dan dapat membuat siswa merasa tertarik untuk melaksanakan tugas yang diberikan.

Selain metode pembelajaran mempengaruhi pembentukan pengalaman belajar, ternyata metode pembelajaran juga memberikan sumbangan pada sikap belajar siswa. setelah dilaksanakan pengolahan data, maka didapatkan bahwa sikap belajar yang tampak dominan adalah adanya perbedaan sikap belajar berdasarkan posisi duduk siswa. siswa yang duduk dibarisan depan kelas terlihat lebih aktif saat kegiatan pembelajaran dibandingkan dengan siswa yang duduk di bagian belakang. Hal ini menimbulkan kemonotonan sikap belajar siswa. sikap belajar sedikit banyak juga menunjukkan seberapa besar minat siswa dalam belajar. semakin besar minat belajarnya maka sikap belajar yang akan diperlihatkan oleh siswa juga akan semakin baik.

Jika ditinjau dari sisi siswa secara personal, siswa lebih meminati pelajaran Fisika untuk materi pelajaran yang banyak melibatkan kemampuan berhitung, siswa kurang sekali meminati untuk membaca buku yang berkaitan dengan ilmu-ilmu alam. Karena mereka beralasan bahwa menyelesaikan soal-soal Fisika yang banyak melibatkan kemampuan berhitung itu lebih mengasyikkan. Minat belajar seperti itu dipengaruhi oleh pengalaman belajar yang telah didapatkan oleh siswa pada tingkat sebelumnya. Jika pengalaman belajar yang mereka dapatkan itu baik maka akan menimbulkan ketetapan minat belajar siswa.

Selain itu minat belajar siswa juga akan mempengaruhi kesiapan belajar siswa dan juga kesadaran siswa untuk memenuhi segala hal yang berkaitan dengan kecenderungan minat. Dimana hal tersebut dapat terlihat dari sikap belajar yang ditunjukkan oleh siswa itu sendiri. Selain itu kesiapan dan kesadaran dalam belajar sedikit banyak akan menciptakan cara belajar yang berbeda-beda pada tiap siswa, yang menurut siswa mampu menunjang kebutuhan mereka dalam memaksimalkan kegiatan belajar.

Ciri-ciri siswa berminat belajar Fisika

1) Aktif saat belajar di kelas

2) Memiliki rasa ingin tahu yang tinggi

3) Seorang Kompetitor

4) Memiliki kesadaran diri

5) Bertanggung jawab

6) Pantang menyerah.

7) Antusias saat belajar

Faktor yang Mempengaruhi Minat Belajar Fisika Siswa.

a. Faktor Internal

1. Kemampuan dasar 
2. Rasa tanggung jawab

3. Kesadaran diri

4. Cara belajar

5. Pengalaman belajar sebelumnya

6. Kesiapan belajar

b. Faktor eksternal

1. Metode pembelajaran di kelas

2. Cara guru mengajar di kelas

3. Ketersediaan fasilitas belajar

4. Kompetisi di lingkungan belajar

5. Pengaruh lingkungan belajar

\section{Simpulan}

Berdasarkan hasil penelitian dan pengolahan data secara triagulasi data kualitatif yang dilakukan maka dapat ditarik kesimpulan sebagai berikut:

1. Secara keseluruhan, metode pembelajaran yang dipilih guru untuk diterapkan di kelas pada saat pembelajaran Fisika berlangsung sangat mempengaruhi tingkat ketertarikan siswa untuk belajar dan minat belajar siswa.

2. Metode pembelajaran yang dipilih oleh guru juga akan mempengaruhi pengalaman belajar yang dimiliki oleh siswa.

3. Ketertarikan ataupun minat belajar siswa akan mengatur bagaimana kesadaran diri dan juga tanggung jawab siswa dalam belajar yang terlihat dari cara belajar yang mereka rutin lakukan dan kesiapan diri dalam belajar.

4. Ketertarikan dan minat belajar siswa kelas XI MIA 3 SMA Negeri 2 Kota Jambi untuk pelajaran Fisika secara umum dapat dilihat dari sikap belajar yang ditunjukan siswa selama kegiatan belajar Fisika di sekolah, maupun dari kegiatan yang siswa sering lakukan di luar jam sekolah.

5. Posisi duduk siswa saat belajar di kelas tampaknya juga mempengaruhi sikap belajar yang ditunjukkan oleh siswa

6. Pada saat mempelajari pelajaran Fisika di sekolah maupun di rumah siswa lebih meminati materi pelajaran Fisika yang lebih banyak melibatkan kemampuan berhitung.

7. Metode pembelajaran dengan pemberian tugas tanpa memperhatikan kesesuaian materi dan keadaan siswa akan mempengaruhi peningkatan dan penurunan minat belajar siswa.

\section{Referensi}

Chaplin, J.P., 2009, Kamus Lengkap Psikologi,edisi-7, terjemahan K.Kartono, Rajawali Pers, Jakarta.

Creswell, J.W., 2007. Qualitative Inquiry and Research Design: Choosing among Five Approaches. California: Sage Publication,Inc.

2012. Educational Research: Planning, Conducting, and Evaluating Quantitative and Qualitative Research. Boston: Pearson Education.

Dimyati, dan Mudjiono, 2009. Belajar dan Pembelajaran. Jakarta: Rineka Cipta.

Djaali, 2013. Psikologi Pendidikan. Jakarta: Bumi Aksara.

Dwilestari,N., 2012. Penelitian Kualitatif Pendidikan Anak Usia Dini. Jakarta: Rajawali Pers.

Hurlock, B.E., 1978, Perkembangan Anak, edisi-6, terjemahan M. Tjandrasa, Penerbit Erlangga, Jakarta.

Kurniawan, P.V., 2012, Penerapan Metode Demontrasi Berbantuan Alat Peraga untuk Meningkatkan Minat dan Motivasi siswa dalam pembelajaran Fisika, Jurnal Penelitian Pembelajaran Fisika., 3 (2):103109.

Rusilowati,A., 2006, Profil Kesulitan Belajar Fisika Pokok Bahasan Kelistrikan Siswa SMA di Kota Semarang, Jurnal Pendidikan Fisika Indonesia, 4(2): 100-101. 
Saldana, J., 2009. The Coding Manual For Qualitative Researchers. California: Sage Publication, Inc.

Sarwono,W.S., 2010. Pengantar Psikologi Umum. Jakarta: Rajawali Pers.

Sugiyono, 2013. Metode Kuantitatif, Kuantitatif dan R\&D. Bandung: Alfabeta.

Sukada. K., Sadia. W., dan Yudana.M., 2013, Kontribusi Minat Belajar, Motivasi Berprestasi dan kecerdasan Logis Matematika Terhadap Hasil Belajar Matematika Siswa SMA 1 Kintamani, $e$ journal Program Pascasarjana Universitas Pendidikan Ganesha Studi Administrasi Pendidikan, 4: 2-4.

Yuliana, D.Z., dan Nyoman, N.A., 2010, Upaya Meningkatkan Minat Siswa pada Pembelajaran Fisika Berperspektif CRC(Children Rights Convention) dengan Menggunakan Pendekatan Kontekstual, Jurnal Penelitian Pembelajaran Fisika., 1 (2) : 109-203. 